\title{
A new form of familial multi-nodular goitre with progression to differentiated thyroid cancer
}

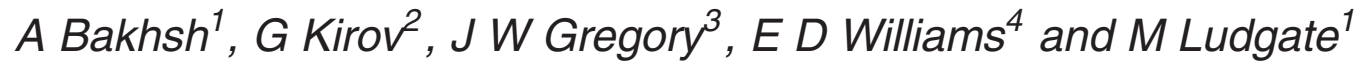

\author{
${ }^{1}$ Centre for Endocrine and Diabetes Sciences, ${ }^{2}$ Department of Psychological Medicine, and ${ }^{3}$ Department of Child Health, School of Medicine, \\ Cardiff University, Heath Park, Cardiff CF14 4XN, UK \\ ${ }^{4}$ Strangeways Laboratory, Cambridge, UK
}

(Requests for offprints should be addressed to M Ludgate; Email:Iudgate@cf.ac.uk)

\begin{abstract}
We report a kindred with euthyroid multi-nodular goitre (MNG) of adolescent onset. Two of the seven subjects with MNG have progressed to papillary thyroid cancer. One affected male had nodular kidney disease, and breast cancer occurred in one affected female. Genes that were candidates on the basis of the associated kidney (PAX8) and breast diseases (sodium iodide symporter (NIS)), were sequenced. No mutations were found in the coding region, intron/exon splice sites or in the promoter sequences (from -1248 relative to the translation initiation codon) of PAX8. Similar results were obtained for NIS. Subsequently, microsatellite analyses were performed on 14 informative family members. We used 2 to 3 markers per locus for 6 loci (on chromosomes $1,2,3,14,19, X)$ previously reported to predispose to MNG and/or familial non-medullary thyroid cancer (FNMTC). On the basis of non-significant logarithm of the odds ratio (LOD) scores or inheritance of different alleles in affected individuals, all loci have been excluded. Thyroidectomy specimens from three members of the kindred show multiple benign lesions, with papillary cancer in two. The morphological features do not resemble those seen in familial adenomatous polyposis, Cowden syndrome, or in multiple oxyphil lesions. From these findings and from the absence of any linkage to any of the known loci associated with MNG or FNMTC, we suggest that this represents a new form of inherited MNG with a significant risk of progression to papillary carcinoma.
\end{abstract}

Endocrine-Related Cancer (2006) 13 475-483

\section{Introduction}

Thyroid enlargement is common in iodine-deficient areas. It is not infrequent (in adults) in countries with an adequate iodine intake, as illustrated by the Whickham survey, which found a goitre in $23 \%$ of women and $5 \%$ of men, decreasing to $10 \%$ and $2 \%$ respectively at 20-year follow-up (Vanderpump et al. 1995). A history of benign thyroid disease is a significant risk factor for the development of thyroid cancer (Musholt et al. 2000), which affects $0.5-10$ individuals per 100000 per year.

The differentiated thyroid cancers, papillary and follicular, arise from follicular cells and account for $90 \%$ of cases of thyroid malignancy (reviewed in Ludgate \& Evans 2004). They are familial in $7-9 \%$ of cases, and linkage to a range of loci has been established, but the genes involved are known in only a small minority of these cases. In contrast, there has been much more progress in delineating the molecular defect in sporadic thyroid cancers. Chromosomal rearrangements which lead to the activation of the RET proto-oncogenes without the need for ligand binding have been identified in papillary thyroid carcinomas (Grieco et al. 1990). More recently, BRAF mutations have been described in a significant proportion of papillary carcinomas (Kimura et al. 2003, Soares et al. 2003), and the great majority of papillary carcinomas show either a BRAF mutation or a rearrangement, usually involving RET, rarely TRK. Translocations between chromosomes 2 and 3 have been detected in a series of follicular tumours, producing an in-frame fusion of PAX8 to peroxisome proliferator-activated receptor gamma (PPAR $\gamma$ ) (Kroll et al. 2000, Cheung et al. 2003). In addition, around $50 \%$ of both benign 
and malignant follicular tumours display RAS activation (Nikiforova et al. 2003). All 3 RAS genes can be involved.

Familial non-medullary thyroid cancer (FNMTC) and its relationship with familial multinodular goitre (MNG) are now recognised as clinical entities. Linkage analysis using microsatellite markers has identified three MNG loci. MNG1 was mapped using a single large Canadian family with adolescent onset of euthyroid MNG in both males and females (Bignell et al. 1997). The locus is at $14 \mathrm{q}$ but does not include the gene for the thyrotrophin (TSH) receptor at $14 q 31$. Study of 37 smaller FNMTC pedigrees indicated that only a small proportion of this disorder is attributable to MNG1. As MNG occurs approximately five times more frequently in women than in men, and in the absence of male-to-male transmission in an Italian kindred, Capon and colleagues investigated the $\mathrm{X}$ chromosome. They obtained a significant logarithm of the odds ratio (LOD) score for chromosome Xp22, referred to as MNG2 (Capon et al. 2000). Locus 3q26.1-q26.3 (MNG3) was identified by linkage analysis of two unrelated Japanese families with MNG (euthyroid but with elevated serum TSH) in several generations (Takahashi et al. 2001).

In the case of FNMTC, several further loci have been implicated. A susceptibility gene was located at $2 \mathrm{q} 21$ in a large Tasmanian family with the follicular variant of papillary carcinoma. The significance of the locus (which apparently does not contain the gene for PAX8) was confirmed by linkage analysis of 80 pedigrees that produced a LOD score of 3.07 (McKay et al. 2001). A gene predisposing to thyroid cancers with follicular and papillary architecture accompanied by cell oxyphilia has been identified at 19p13.2 (Canzian et al. 1998). More recently, a study of ten families with FNMTC found interaction between the 2q21 and 19p13.2 loci. Interestingly, the tumours in 9 of the 10 families showed cell oxyphilia (McKay et al. 2004). The linkage to the locus at $19 \mathrm{p} 13.2$ is not necessarily to the TCO gene, as a second gene (GRIM 19) at this locus has been found to be mutated in some sporadic oxyphil tumours (Maximo et al. 2005).

Locus 1q21 has also been linked with a phenotype of papillary thyroid cancer associated with renal neoplasia and occasional pre-menopausal breast cancer (Malchoff et al. 2000).

FNMTC is a group of discrete syndromes, each characterised by mutation in a different gene, and in most cases by differing morphology in the associated tumours. Furthermore, mutations in the adenomatous polyposis coli gene (5q21-22) correlate with multiple tumours having a distinct morphology, which have been termed familial adenomatous polyposis (FAP)-associated thyroid carcinomas (Harach et al. 1994), and mutations in PTEN (phosphatase and tensin homologue, 10q23.31) that are associated with multiple nonoxyphil follicular adenomas, which may progress to carcinoma (Liaw et al. 1997).

We report our findings of a family with adolescent onset of MNG progressing to papillary thyroid cancer. Characterisation of the gene defect would have obvious benefits for the family in terms of promoting genetic counselling and health screening, as well as contributing to our understanding of thyroid neoplasia. We have therefore studied two candidate genes, and carried out linkage studies to ascertain whether this family represents a previously described type of MNG or FNMTC, or is a new entity.

\section{Case reports and family history}

\section{Index patient}

The index patient (IV 2), a 12-year-old girl born in 1990 and residing in an iodine-sufficient area, presented with MNG. Ultra-sound scan showed multiple hyper-echoic thyroid nodules (three in the left and one in the right lobe). Fine needle aspirate (FNA) histology showed no evidence of malignancy. Pre-operative thyroid function tests showed normal TSH $(1.4 \mathrm{mU} / 1$; normal range $0.35-5.5 \mathrm{mU} / 1)$ and normal free thyroxine $\left(\mathrm{T}_{4}\right)(16.2 \mathrm{pmol} / \mathrm{l}$; normal range 9.8-23.1 pmol/1), confirming a euthyroid condition. TSH receptor (TSHR) antibodies, were negative, and thyroid peroxidase (TPO) antibodies were within the normal range $(8.6 \mathrm{kU} / 1$; normal range $<32.0 \mathrm{kU} / 1)$. In addition, the thyroglobulin (TG) antibodies were $2.2 \mathrm{kU} / 1$ (normal range $<46.0 \mathrm{kU} / 1)$. The karyotype was normal, as was the kidney scan. In view of the family history, a total thyroidectomy was carried out and multiple adenomas were found with no evidence of malignancy. The patient is currently euthyroid, receiving daily replacement with thyroxine.

\section{Family history}

There is a strong family history of MNG, progressing to papillary thyroid cancer in two members of the family, as shown in the family tree (Fig. 1). 


\section{Family Tree}

I

II

III

IV

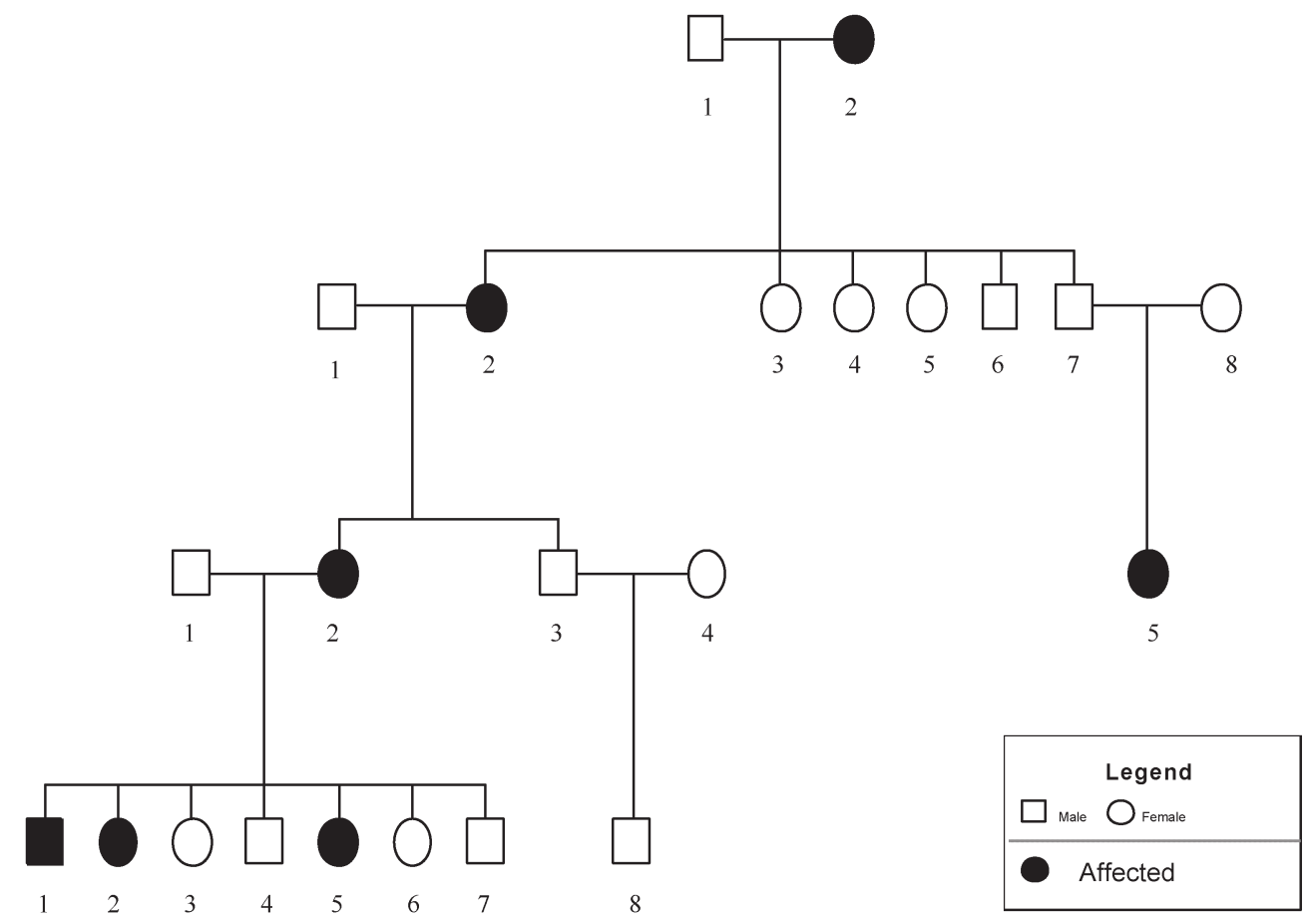

Figure 1 Family tree showing four generations of affected individuals. The propositus is individual IV 2.

Although physical examination of the thyroid of the girl's 18-year-old brother (IV 1) (born in 1984) was normal, a thyroid scan revealed 8 or 9 hyperechoic cysts. His FNA showed changes suggestive of papillary thyroid cancer. He also underwent total thyroidectomy. In infancy, he had undergone nephrectomy for polycystic kidney disease. No other member of the family was demonstrated to have any abnormality on renal ultrasound examination.

Her 22-year-old sister (IV 5) (born in 1980) has MNG but a thyroid scan revealed small hypoechoic cysts. She did not undergo thyroidectomy but will be carefully followed.

The girl's mother (III 2) (born in 1961) underwent partial thyroidectomy at the age of 17 for MNG. At the age of 27, she underwent a second partial thyroidectomy and at age 28 she had a total thyroidectomy for papillary carcinoma. She has recently developed breast carcinoma, at age 41 .

One brother (IV 4) (born in 1989) and one sister (IV 6) (born in 1986) have no signs of thyroid or kidney lesions, both are post-puberty. A second brother (IV 7) (born in 1982) has not been examined; one sister is pre-pubertal (IV 3) (born in 1994).
A maternal uncle (III 3) and his family have no signs of thyroid or kidney lesions. By contrast, her maternal grandmother (II 2), great-grandmother (I 2) and mother's first cousin (III 5) underwent surgery for presumed benign thyroid disease.

The father's (III 1) side of the family has no history of MNG or thyroid dysfunction.

\section{Materials and methods}

\section{Sample collection and preparation}

EDTA blood samples were obtained from individuals (I 2; II 2, 7, 8; III 1, 2, 3, 5; and IV 1, 2, 3, 4, $5,6)$ all with informed consent and ethical approval. Genomic DNA was extracted using the QIAamp blood kit, according to the manufacturer's instructions (Qiagen) and was quantified spectrophotometrically.

\section{Candidate genes}

PAX8 is a paired-box-containing transcription factor expressed in thyroid and kidney, and shown to be involved in the genesis of several Wilm's tumours (Poleev et al. 1992). Some types of unilateral polycystic disease in infants have a male 
predominance (Lazebnik et al. 1999), suggesting that the associated thyroid and kidney disease could be due to mutations in PAX8. Sodium iodide symporter (NIS), expressed in thyroid, breast and some other tissues, results in the transport of iodide, which is essential for thyroid hormone production, and through a short loop feedback is postulated to have a direct effect on thyroid growth. Somatic mutations in the NIS gene in the thyroid in a family with a germline mutation in one NIS allele could give the affected follicular cells a growth advantage, potentially leading to the formation of a nodule. A similar mechanism has been postulated for the thyroid peroxidase gene (Krohn \& Paschke 2001).

\section{Sequencing studies}

Genomic DNA was PCR amplified in a $50 \mu \mathrm{l}$ reaction volume containing $3 \mu \mathrm{l}$ DNA $(100 \mathrm{ng} / \mathrm{l})$, $5 \mu \mathrm{l}$ PCR buffer $(10 \times)\left(1.5 \mathrm{mM} \quad \mathrm{MgCl}_{2}\right), 2 \mu \mathrm{l}$ dNTP $(10 \mathrm{mM})$ (Promega), $2 \mu \mathrm{l}$ forward primer $(10 \mathrm{pmol} / \mathrm{l})$ (Invitrogen), $2 \mu \mathrm{l}$ reverse primer $(10 \mathrm{pmol} / \mathrm{l})$ and $1 \mu \mathrm{l}$ Taq polymerase $(1 \mathrm{U} / \mathrm{l})$ (Promega). Reactions were performed using a Genius Techne machine: 1 cycle, $95^{\circ} \mathrm{C}$ for $2 \mathrm{~min}$; 30 cycles, $94^{\circ} \mathrm{C}$ for $1 \mathrm{~min}, \mathrm{X}^{\circ} \mathrm{C}$ for $1 \mathrm{~min}, 72^{\circ} \mathrm{C}$ for $1 \mathrm{~min}$; 1 cycle, $72^{\circ} \mathrm{C}$ for $5 \mathrm{~min}$. For each primer pair, conditions were optimised for annealing temperature $(\mathrm{X}), \mathrm{MgCl}_{2}$ concentration and the presence/absence of DMSO.

Previously described (Macchia et al. 1998) PAX8 promoter and intronic primers were used. The NIS was amplified using primers designed using Primer 3 software (http://frodo.wi.mit.edu/cgi-bin/primer3) (Table 1).

PCR products were polyethylene glycol (PEG)precipitated and sequenced in a $10 \mu \mathrm{l}$ reaction containing $2 \mu \mathrm{l}$ Big Dye Terminator Cycle Sequencing Ready Reaction (ABI Prism, PE Biosystems, Foster City, CA, USA), $1 \mu 1$ primer (10 pmol/l) and approximately $25 \mathrm{ng}$ PEG-precipitated PCR. Sequencing reactions were run on a Genius (Techne) PCR machine, using the same annealing temperature for each individual primer as had been used for the primer combination. The products were sodium acetate-precipitated and analysed on an ABI Prism 377.

\section{Microsatellite analysis}

Primer pairs flanking microsatellites in the vicinity of the six known MNG/FNMTC loci were selected from the ABI Version 2.5 set using the genome browser gateway (www.genome.ucsc.edu). Details are shown in Table 2.

The genotyping commenced with PCR amplification in a $12 \mu \mathrm{l}$ reaction volume, which contained $24 \mathrm{ng}$ (in $2 \mu \mathrm{l}$ ) genomic DNA, $200 \mu \mathrm{M}$ dNTPs (Amersham), 0.4-0.5 $\mu$ l primer mix ( $5^{\prime}$ fluorescent labelled) (Applied Biosystems) (at 10 pmol dilution), $1.5 \mathrm{mM} \mathrm{MgCl}$ and 0.5 U Taq polymerase (Qiagen).

Sixteen PCRs (1 for each primer pair) were performed on the 14 individuals ( 3 duplicated) and the UK pool. The reactions were performed in 96well plates (AB Gene, Epsom, Surrey, UK) using an MJ Engine Tetrad PCR machine. After initial denaturation and activation of the Taq at $95^{\circ} \mathrm{C}$ for $15 \mathrm{~min}$, we performed 3 cycles of touch-down PCR starting from $62^{\circ} \mathrm{C}$, followed by 30 cycles of $95^{\circ} \mathrm{C}$ for $20 \mathrm{~min}, 58^{\circ} \mathrm{C}$ for $30 \mathrm{~min}$ and $72^{\circ} \mathrm{C}$ for $45 \mathrm{~min}$. A final extension step at $72^{\circ} \mathrm{C}$ for $10 \mathrm{~min}$ was performed.

The PCR amplicons underwent agarose gel electrophoresis to confirm that the expected size

Table 1 Primer sequences forward $(F)$ and reverse $(R)$ used to amplify the exons (1-15) of the sodium iodide symporter (NIS) and the size in base pairs (bp) of the resulting amplicons.

\begin{tabular}{|c|c|c|}
\hline Exon & Sequence $\left(5^{\prime}-3^{\prime}\right)$ & Size bp \\
\hline $\mathrm{F} 1 \mathrm{~A} / \mathrm{R} 1 \mathrm{~A}$ & GCAGGACAGACAGACAGCAG/ATAGCGATAGGCCTCCGAC & 550 \\
\hline $\mathrm{F} 1 \mathrm{~B} / \mathrm{R} 1 \mathrm{~B}$ & CTTCGGAGCCTGGGACTAC/CTGTACAGCGGCCCAAAG & 418 \\
\hline $\mathrm{F} 2 / \mathrm{R} 2$ & CCCACCTAGAGAGCAGACCA/GCAGATAGGCCGGGTCTT & 374 \\
\hline $\mathrm{F} / \mathrm{R} 3 \& 4$ & САСССТTСТGССТССТСТС/ CCAGAGTCTССССАСAAGAG & 386 \\
\hline F5/R5 & GTCCTAGGCACCACTGAAGG/CTCAACTACCTGGGACCACA & 477 \\
\hline F/R6 \& 7 & TCCCCTATAAGGTCCAGAAGC/TCCСTCTGCTAGGAATGCTC & 553 \\
\hline F8/R8 & TGCATATTAAATGCCGACTCTG/TCTTCTAGGGATCAAGCAGGA & 351 \\
\hline F/R9 \& 10 & GGAGGGGCAAATATCTCCTT/TGAGTTCTGCCACTGACACAT & 513 \\
\hline $\mathrm{F} / \mathrm{R} 11 \& 12$ & GTTCCTGAGGTCTCGCTTTC/ CACAGAGTGCAGGGCAAGTA & 586 \\
\hline F13/R13 & AATGGAGGTCTGTGCTAGGC/ACAGCACACAGTGGCAGTTT & 368 \\
\hline $\mathrm{F} 14 / \mathrm{R} 14$ & GTGGGACTGGAGCCTGTTAG/ATGAGCGATGGAGAAAGGTG & 351 \\
\hline $\mathrm{F} 15 / \mathrm{R} 15$ & AGATGAGCTGACACGGAACA/ GATCACACCACTGCACTCCA & 572 \\
\hline
\end{tabular}


Table 2 Microsatellite markers selected for the known multinodular goitre (MNG) and familial non-medullary thyroid cancer (FNMTC) loci indicating the labelling dye, location, size in base pairs (bp) of expected amplicons, and chromosomal intervals.

\begin{tabular}{|c|c|c|c|c|c|}
\hline Locus & Markers & Dye & Location & Size (bp) & Intervals \\
\hline \multirow[t]{3}{*}{ MNG1 } & d14s280 & Fam & $90,072,907$ & 243-263 & \\
\hline & d14s65 & Ned & $95,511,512$ & $129-161$ & $5 \mathrm{cM}$ \\
\hline & d14s985 & Hex & $99,386,856$ & 244-285 & $4 \mathrm{cM}$ \\
\hline \multirow[t]{3}{*}{ MNG2 } & dxs1226 & Ned & $22,208,848$ & $200-381$ & \\
\hline & dxs986 & Fam & $78,036,903$ & $200-340$ & $56 \mathrm{cM}$ \\
\hline & dxs1001 & Hex & $118,490,628$ & 200-354 & $40 \mathrm{cM}$ \\
\hline \multirow[t]{3}{*}{ MNG3 } & d3s1614 & Ned & $169,631,284$ & $107-131$ & \\
\hline & d3s1565 & Fam & $174,703,580$ & $182-198$ & $5 \mathrm{cM}$ \\
\hline & d3s1262 & Fam & $187,444,391$ & $115-137$ & $13 \mathrm{cM}$ \\
\hline \multirow[t]{3}{*}{ FNMTC1 } & d19s884 & Ned & $7,955,955$ & $97-117$ & \\
\hline & d19s221 & Hex & $12,473,742$ & $91-115$ & $4 \mathrm{cM}$ \\
\hline & d19s226 & Ned & $14,394,399$ & $241-273$ & $2 \mathrm{cM}$ \\
\hline \multirow[t]{2}{*}{ FNMTC2 } & d2s347 & Fam & $124,244,954$ & 271-301 & \\
\hline & d2s112 & Fam & $133,319,465$ & 79-95 & $9 \mathrm{cM}$ \\
\hline \multirow[t]{2}{*}{ FNMTC3 } & d1s498 & Ned & $148,418,077$ & 200-361 & \\
\hline & d1s484 & Hex & $157,884,102$ & $276-290$ & $9 \mathrm{cM}$ \\
\hline
\end{tabular}

range of fragments had been obtained, and capillary electrophoresis to assess the peak height when compared with the ROX labelled molecular weight standards.

To minimise the number of reactions, 2-3 PCR products of different size ranges/differing dyes were pooled for analysis. A $10.5 \mu 1$ multiplex reaction volume contained $2 \mu \mathrm{l}$ pooled PCR products, $8 \mu \mathrm{l}$ HiDi formamide (Applied Biosystems) and $0.5 \mu 1$ Size standard (400 bp) (Applied Biosystems). The samples were size separated on an ABI 3100 Genetic Analyser, using the Genescan program (Applied Biosystems) for 'allele calling'. A LOD score was calculated for each marker, based on $100 \%$ penetrance in women, $50 \%$ penetrance in males, dominant mode of transmission and no phenocopies.

\section{Histopathological examination of thyroids}

The thyroid tissues were formalin fixed and embedded in paraffin prior to the generation of 5-10 micron sections and standard haemotoxylin and eosin staining.

\section{Results}

\section{Sequencing candidate genes}

The sequences of the coding region, intron/exon splice sites and promoter, from -1248 relative to the 'start' of PAX8 were identical in the unaffected father (III 1) and the affected son (IV 1). Furthermore, the sequences of both family members were compared with those for PAX8 available in the NCBI database, www.ncbi.nlm.nih.gov (Accession numbers, NM_003466, BC001060, L19606.1, AB062505 and X69699). The comparison has detected three different polymorphisms, including in the promoter region. One version has four missing base pairs, GGGC or GCGG at position -479 . Both members of the family tested were homozygous for this deletion polymorphism.

Similar results were obtained for NIS, with the sequences of the unaffected father (III 1) and the affected mother (III 2) being identical. Four reported sequences of NIS were identified in the NCBI database (Accession numbers, HSU66088, NM 000453.1, AC005796 and D87920.1). The first three, published by USA authors, are identical and match the sequences of NIS obtained in the two family members investigated. The fourth is published by Japanese authors and reports several polymorphisms, the most notable being (1) a $\mathrm{G}$ to C transition changing proline 102 to alanine; (2) an $\mathrm{AC}$ to $\mathrm{CA}$ transversion at 536 (in the $2 \mathrm{nd}$ and $3 \mathrm{rd}$ bases) which changes thymine to glutamine; (3) substitution of $\mathrm{CAG}$ by $\mathrm{AGC}$ at 556 which changes serine to glutamine; and (4) 120 bases missing from the $3^{\prime}$ non-coding region (the last part of exon 15) between 1206 and 1086 base pairs before the polyA tail.

\section{Microsatellite analysis}

Microsatellite analysis produced a non-significant LOD score for all six loci tested, as shown in Table 3. 


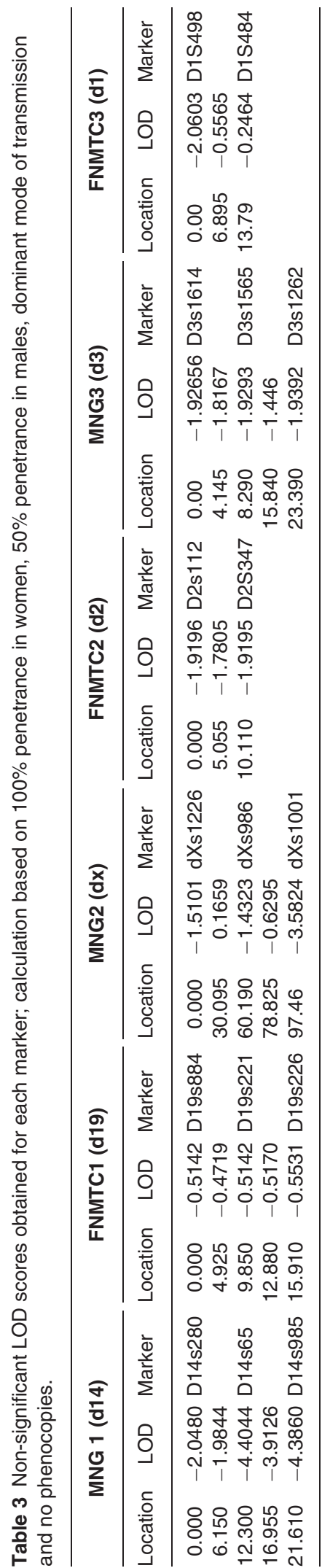

Further evidence for the exclusion of these loci as containing genes predisposing to familial $\mathrm{MNG}$ or FNMTC was provided by detailed examination of the alleles inherited. In some instances affected individuals inherited different alleles from their affected mother. In contrast, the same maternal alleles were inherited by non-affected and affected children. FNMTC1 (d19) is used as an example to illustrate this in Fig. 2.

\section{Histopathological examination of thyroid glands}

Thyroid tissue was available from three members of the family. The findings in the thyroidectomy specimens from the propositus (IV 2), and the first specimen from her mother (III 2) were essentially similar, with multiple benign nodules composed of colloid-rich follicles often with some papillary infolding. The second specimen from the mother showed a papillary carcinoma (follicular variant) throughout the resected tissue, also present in the total thyroidectomy specimen. The thyroidectomy specimen from the brother (IV 1) showed benign adenomas similar to his sister, but no evidence of papillary carcinoma, as had been detected in the FNA. The nuclear features of papillary carcinoma that were present in the latter two specimens were absent from the benign lesions. The lesions arose in otherwise normal thyroid tissue, they were not oxyphil, and did not show the features of FAPassociated tumours.

\section{Discussion}

In a population with adequate iodine intake, nodular goitre in children is extremely rare. The fact that nodular goitre presented in childhood in this family, coupled with the uniformity of gland histology (in those cases where resected material was available) justifies the assumption that this is a genetically determined condition.

Initially, genes that were candidates on the basis of the accompanying kidney (PAX8) and breast diseases (NIS) were examined. In both PAX8 and NIS the sequences of an affected and a nonaffected family member were identical, thereby eliminating these genes as a cause. Of interest, a number of polymorphic variations for each of the two genes were identified. In the case of PAX8, the promoter region varies by four base pairs. Promoter polymorphisms have been shown to influence transcription rates, although this is 


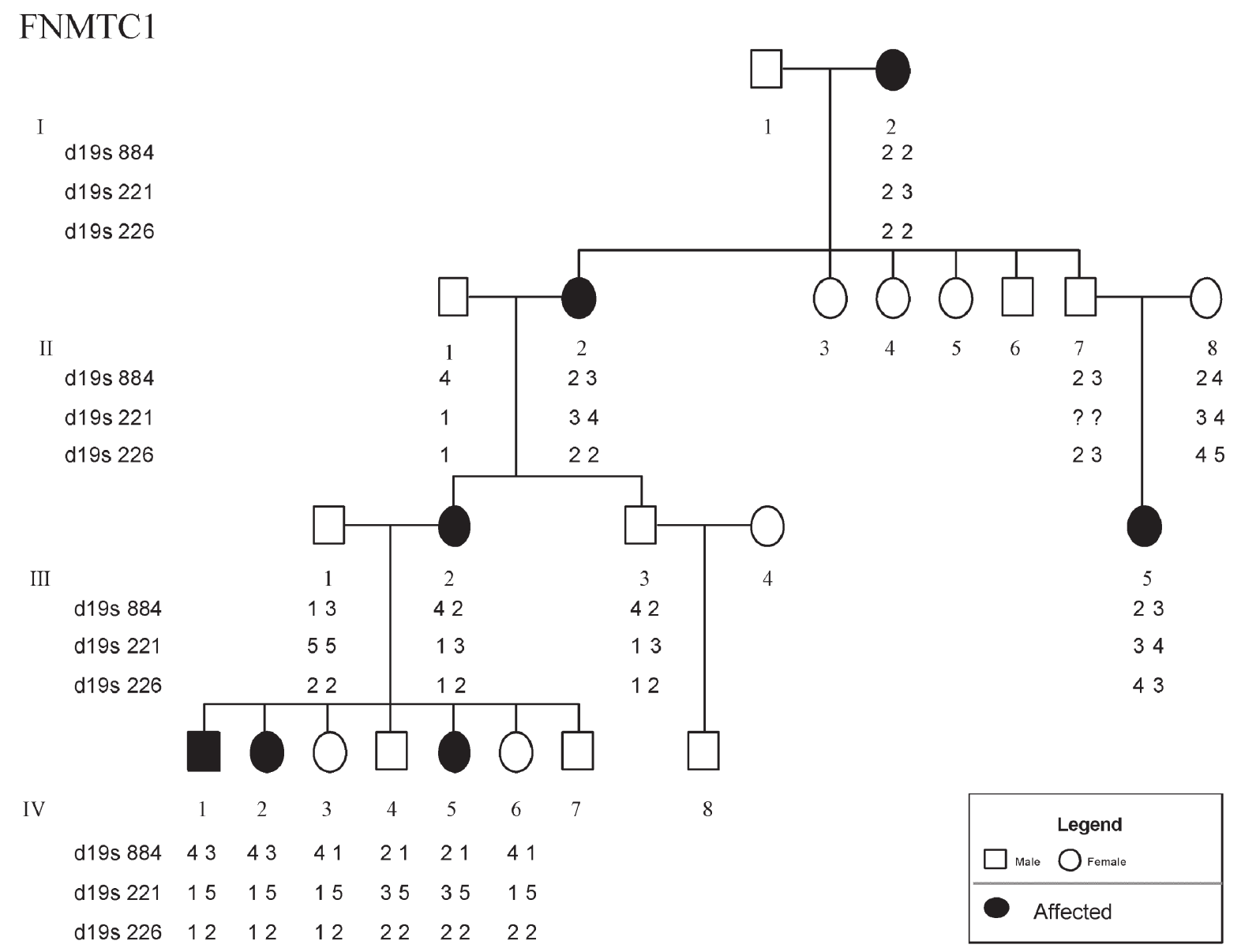

Figure 2 Microsatellite analysis of FNMTC1. Individuals III 3 and III 2 inherited the same maternal (II 2) allele; III 3 is not affected. Individuals IV 5 and IV 1 inherited different maternal (III 2) alleles; both are affected.

unlikely to be of relevance to the family. Some of the NIS polymorphisms have the capacity to alter the biological activity of the symporter or to modulate the stability of the mRNA. It would be interesting to compare the iodide trapping capabilities of the variant NIS forms.

Six loci were investigated using microsatellite analysis and in all cases we obtained LOD scores $<1$. This may be partly explained by the relatively small number of individuals analysed $(n=14)$. However, for each locus, different 'affected' maternal alleles were inherited by affected offspring or first degree relatives, providing a further exclusion criterion.

Although several thyroid-specific genes were eliminated by our investigations, linkage analysis of MNG1 did not exclude thyroid transcription factor 1 (TTF1) as a cause of the phenotype. TTF1 is located between $34,978,942$ and $34,975,641$ on chromosome 14, while the MNG1 loci are at $90,072,907$ to $99,386,856$ on the same chromosome.

Whilst these results were being analysed, four further loci for euthyroid MNG were reported on chromosomes $2 \mathrm{q}, 3 \mathrm{p}, 7 \mathrm{q}$ and $8 \mathrm{p}$, based on a dominant model with reduced penetrance (Bayer et al. 2004). The study also highlighted several features of the disease including its heterogeneity and possible polygenic nature. The cohort comprised multiple unrelated families with benign disease, unlike the present study of a single kindred with a consistent morphological phenotype, implying a homogeneous pathogenetic process.

The role of previously reported somatic rearrangements and mutations identified in sporadic thyroid cancer was also considered. Karyotype analysis of two affected family members (IV 1 and 2) revealed no gross chromosomal abnormality, thereby eliminating translocations as the cause. We would expect germline mutations in RAS or 
BRAF to produce a more severe phenotype, as these oncogenes are involved in a wide range of malignancies.

Future studies aimed at identifying the genetic cause of $\mathrm{MNG}$ and papillary thyroid carcinoma in the family could include whole-genome linkage analysis. This could be performed using microsatellite markers but recent reports suggest that more information and higher LOD scores can be obtained using single nucleotide polymorphisms to identify loci (Evans \& Cardon 2004). Through a combination of genetic analysis and morphological criteria, we conclude that the gene(s) predisposing to MNG and FNMTC in this family are different from those described in other kindred.

\section{Acknowledgements}

We are grateful for the continued support of Professor Maurice Scanlon, and to Dr John Rees for performing and interpreting ultrasound scans. We also wish to express our thanks for the wholehearted participation of the family who are the subject of this study.

\section{Funding}

A B was funded by the government of Saudi Arabia. All authors wish to declare that they have no conflicts of interest that would prejudice their impartiality and have not received support for the study from any commercial source.

\section{References}

Bayer Y, Neumann S, Meyer B, Ruschendorf F, Reske A, Brix T, Hegedus L, Langer P, Nurnberg P \& Paschke R 2004 Genome-wide linkage analysis reveals evidence for four new susceptibility loci for familial euthyroid goiter. Journal of Clinical Endocrinology and Metabolism 89 4044-4052.

Bignell GR, Canzian F, Shayeghi M, Stark M, Shugart YY, Biggs P, Mangion J, Hamoudi R, Rosenblatt J, Buu P, Sun S, Stoffer SS, Goldgar DE, Romeo G, Houlston RS, Narod SA, Stratton MR \& Foulkes WD 1997 Familial nontoxic multinodular goiter locus maps to chromosome $14 \mathrm{q}$ but does not account for familial nonmedullary thyroid cancer. American Journal of Human Genetics $\mathbf{6 1}$ $1123-1130$.

Canzian F, Amati P, Harach R, Kraimps JL, Leseuer F, Barbier J, Levillain P, Romeo G \& Bonneau D 1998 A gene predisposing to familial thyroid tumours with cell oxyphilia maps to chromosome 19p13.2. American Journal of Human Genetics 63 1743-1748.
Capon F, Tacconelli A, Giardina E, Sciacchitano S, Bruno R, Tassi V, Trischitta V, Filetti S, Dallapiccola B \& Noveili G 2000 Mapping a dominant form of multinodular goiter to chromosome Xp22. American Journal of Human Genetics 67 1004-1007.

Cheung L, Messina M, Gill A, Clarkson A, Learoyd D, Delbridge L, Wentworth J, Philips J, Clifton-Bligh R \& Robinson BG 2003 Detection of the PAX8-PPAR gamma fusion oncogene in both follicular thyroid carcinomas and adenomas. Journal of Clinical Endocrinology and Metabolism 88 354-357.

Evans DM \& Cardon LR 2004 Guidelines for genotyping in genome wide linkage studies: single-nucleotide polymorphism maps versus microsatellite maps. American Journal of Human Genetics 75 687-692.

Grieco M, Santoro M, Berlingieri MG, Melillo RM, Donghi R, Bongarzone I, Pierotti MA, Della Porta G, Fusco A \& Vecchio G 1990 PTC is a novel rearranged form of the ret proto-oncogene and is frequently detected in vivo in human thyroid papillary carcinomas. Cell $60557-563$.

Harach HR, Williams GT \& Williams ED 1994. Familial adenomatous polyposis-associated thyroid carcinoma - a distinct type of follicular cell neoplasm. Histopathology 25 549-561.

Kimura ET, Nikiforova MN, Zhu ZW, Knauf JA, Nikiforov YE \& Fagin JA 2003 High prevalence of BRAF mutations in thyroid cancer: genetic evidence for constitutive activation of the RET/PTC-RAS-BRAF signaling pathway in papillary thyroid carcinoma. Cancer Research 63 1454-1457.

Krohn K \& Paschke R 2001 Loss of heterozygocity at the thyroid peroxidase gene locus in solitary cold thyroid nodules. Thyroid 11 741-747.

Kroll TG, Sarraf P, Pecciarini L, Chen CJ, Mueller E, Spiegelman BM \& Fletcher JA 2000 PAX8-PPAR gamma 1 fusion in oncogene human thyroid carcinoma. Science 289 1357-1360.

Lazebnik N, Bellinger M, Ferguson JN, Hogge J \& Hogge W 1999 Insights into the pathogenesis and natural history of fetuses with multicystic dysplastic disease. Prenatal Diagnosis 19 418-423.

Liaw D, Marsh DJ, Li J, Dahia PL, Wang SI, Bose S, Call KM, Tsou HC, Peacocke M, Eng C \& Parsons R 1997 Germline mutations of the PTEN gene in Cowden disease, an inherited breast and thyroid cancer syndrome. Nature Genetics 16 64-67.

Ludgate M \& Evans C 2004 Thyroid cancer, molecular genetics. In Encyclopedia of the Human Genome. Ed. D Cooper. Nature Publishing Group, London A6177.

Macchia P, Lapi P, Krude H, Pirro M, Missero C, Chiovato L, Souabni A, Baserga M, Tassi V \& Pinchera A 1998 PAX8 mutations associated with congenital hypothyroidism caused by thyroid dysgenesis. Nature Genetics 19 83-86.

McKay JD, Leseuer F, Jonard L, Pastore A, Williamson J, Hoffman L, Burgess J, Duffield A, Papotti M, Stark M et al. 2001 Localization of a susceptibility gene for familial nonmedullary thyroid carcinoma to chromosome $2 \mathrm{q} 21$. American Journal of Human Genetics 69 440-446. 
McKay JD, Thompson D, Lesueur F, Stankov K, Pastore A, Watfah C, Strolz S, Riccabona G, Moncayo R, Romeo G \& Goldgar DE 2004 Evidence for interaction between the TCO and NMTC1 loci in familial non-medullary thyroid cancer. Journal of Medical Genetics 41 407-412.

Malchoff CD, Sarfarazi M, Tendler B, Forouhar F, Whalen G, Joshi V, Arnold A \& Malchoff DM 2000 Papillary thyroid carcinoma associated with papillary renal neoplasia: genetic linkage analysis of a distinct heritable tumor syndrome. Journal of Clinical Endocrinology and Metabolism 85 1758-1764.

Maximo V, Botelho T, Capela J, Soares P, Lima J, Taveira A, Amaro T, Barbosa AP, Preto A, Harach HR, Williams D \& Sobrinho-Simoes M 2005 Somatic and germline mutation in GRIM-19, a dual function gene involved in mitochondrial metabolism and cell death, is linked to mitochondrion-rich (Hurthle cell) tumours of the thyroid. British Journal of Cancer 92 1892-1898.

Musholt TJ, Musholt PB, Petrich T, Oetting G, Knapp WH \& Klempnauer J 2000 Familial papillary thyroid carcinoma: genetics, criteria for diagnosis, clinical features, and surgical treatment. World Journal of Surgery 24 1409-1417.

Nikiforova MN, Lynch RA, Biddinger PW, Alexander EK, Dorn GW, Tallini G, Kroll TG \& Nikiforov YE 2003 RAS point mutations and PAX8-PPAR gamma rearrangement in thyroid tumors: evidence for distinct molecular pathways in thyroid follicular carcinoma. Journal of Clinical Endocrinology and Metabolism 88 2318-2326.

Poleev A, Fickenscher H, Mundlos S, Winterpacht A, Zabel B, Fidler A, Gruss P \& Plachov D 1992 PAX8, a human paired box gene: isolation and expression in developing thyroid, kidney and Wilm's tumors. Development 116 611-623.

Soares P, Trovisco V, Rocha AS, Lima J, Castro P, Preto A, Maximo V, Botelho T, Seruca R \& Sobrinho-Simoes M 2003 BRAF mutations and RET/PTC rearrangements are alternative events in the etiopathogenesis of PTC. Oncogene 22 4578-4580.

Takahashi T, Nozaki J, Komatsu M, Wada Y, Utsonomiya M, Inoue K, Takada G \& Koizumi M 2001 A new locus for a dominant form of multinodular goiter on 3q26.1-q26.3. Biochemical and Biophysical Research Communications 284 650-654.

Vanderpump MPJ, Tunbridge WMG, French JM, Appleton D, Bates D, Clark F, Evans JG, Hasan DM, Rodgers H, Tunbridge F \& Young ET 1995 The incidence of thyroid disorders in the community - a 20-year followup of the Whickham study. Clinical Endocrinology $\mathbf{4 3}$ 55-68. 
